\title{
CDKN2D wt Allele
}

National Cancer Institute

\section{Source}

National Cancer Institute. CDKN2D wt Allele. NCI Thesaurus. Code C122827.

Human CDKN2D wild-type allele is located in the vicinity of $19 p 13$ and is approximately 3 $\mathrm{kb}$ in length. This allele, which encodes cyclin-dependent kinase 4 inhibitor $\mathrm{D}$ protein, plays a role in the negative regulation of cyclin-dependent kinase activity. 